\title{
A new archival hub at Wits University
}

\section{A conversation with Noor Nieftagodien, Head of History Workshop (University of}

\section{Witwatersrand)}

\author{
Matthieu Rey
}

\begin{abstract}
How to cite: Rey Matthieu (2021), "A new archival hub at Wits University. A conversation with Noor Nieftagodien, Head of History Workshop (University of Witwatersrand)", Revue d'Histoire Contemporaine de I'Afrique, online. URL: https://oap.unige.ch/journals/rhca/article/view/entrey
\end{abstract}

Online: 8 October 2021

DOI: https://doi.org/10.51185/journals/rhca.2021.e566

For some years, the archives in South Africa have faced a series of unprecedented challenges that threaten the high quality of the documentation and the functioning of the centers that maintain them. The crises facing the State Archives reflect problems in the state more generally including inadequate strategic investment and lack of training, which jeopardise the potential renewal of archivists. At the same time, the wide array of political activities and social movements, the dynamics of civil society organizations and activism require more than ever to curate documentation and expand the archives' capacities. To answer this paradox, a team working in two independent archives and a research center at Wits University is experimenting with a new "hub" to constitute an important center of independent archives in South Africa. Noor Nieftagodien, director of the Wits History Workshop ${ }^{1}$ - the research center that has played a role in the creation of the hub - and a member of the board of the South African Historical Archives, ${ }^{2}$ sheds light on the new enterprise.

\section{Can you briefly describe the archives in South Africa?}

What one has - this has been the case for decades -in broad terms, are three main kinds of archives. The most significant are the archives that are under the control of state. Until the democratic years, these archives had been created by the white state. Scholars of archives would have located those archives broadly as part of colonial archives. That's self-evident. But saying that, those archives are quite important because, with all the problems associated with

\footnotetext{
1 URL: https://www.wits.ac.za/history-workshop/ (accessed 05.10.2021).

2 URL: https://www.saha.org.za/ (accessed 05.10.2021).
} 
them, they contain an enormous amount of details and information about the South African state in its multiple forms.

Now, in the democratic years, there were several interventions to reframe those archives. Understanding that those archives were inherently problematic and that as a new state came into being, archivists, scholars, and archivist activists (see below) intervened to try to reimagine the archive. That has achieved uneven success. The National Archives, the official archives as anywhere in the world, always reflect the nature of the state. What one has seen for the last few years in South Africa is that the archives have experienced decline in terms of management, effectiveness, collections of archives, organization, preservation, all those sorts of things. This crisis results from a series of factors such as disengagement from the state in terms of concerted attention to the development of the archives. The state did invest funds into the creation of large-scale provincial archives but focused on the erection of new buildings at the expense of effectively reorganizing the archives. Finally, the official National Archives operated at different levels - national, provincial and local levels. They remain very important but face several crises.

There are of course a myriad of personal archives. Then, there are archives that are defined as independent archives, which archives have a number of categories. The one is the archives that are based and supported by universities. They are autonomous because universities are autonomous entities in South Africa. Those archives have varied histories and different identities. They often reflect the kind of places where they are, the city, the province. Some of them have a national imprint. To use a few quick examples, what one has at Free State University, ${ }^{3}$ is that it has become, among others, depositories of material of former National Party leaders. That is because it is a former Afrikaans university, historically associated with apartheid, at least until the democratic era. So, National Party leaders have tended to deposit their archives there. Then you have an archive linked to what it is now, the University of KwaZulu Natal, called the Killie Campbell archives, ${ }^{4}$ and that has various archives, but it is regarded as the most important archive of that province's history. Then there is an archive like Historical Papers ${ }^{5}$ at Wits University which originated with deposits from the Anglican Church. It was always an archive that collected material of entities, organization, and movements, outside of the State and political parties, and over many decades it has accumulated numerous amounts of archives including of the Anglican Church of Southern Africa, SA institute of Race Relation, trade unions and civil society archives, etc. In the period from the 1970s, as the antiapartheid struggle gained momentum, resistance organizations, movements and researchers deposited materials to be preserved in these archives. And that has continued, although less so over the last decade or more.

The archives associated with universities have a degree of security, autonomy and investment by the university in preserving the archives. They have become even more important, as one sees the decline of National Archives. At their origin, they were important because it is where independent archives were placed outside of the control of the Apartheid

\footnotetext{
${ }^{3}$ URL: https://www.ufs.ac.za/library/libraries-divisions/archive-for-contemporary-affairs-home/collections/political-collection (accessed 05.10.2021).

4 URL: https://campbell.ukzn.ac.za/?q=node/42 (accessed 05.10.2021).

5 URL: http://www.historicalpapers.wits.ac.za/ (accessed 05.10.2021).
} 
government. There was a hope that the new government would augment archives; not only National Archives but also support independent archival projects. There was rhetorical support but little material support. So, the independent archives remain important and even more so in the period of crisis.

Then there are archives that were created to keep the material of the liberation movements and were associated with organization and movements of resistance and civil society activism. So, the South African History Archives (SAHA) started as archive that brought together materials of the internal struggle in South Africa and in Zimbabwe. From that, it became an archive that collected materials of activists' organizations, of movements, not only past movements but contemporary movements. This is why SAHA has defined itself as an activist archive, that sees its role not only as preservation but also continuously reimagining itself and collecting materials of current movements. I'll use two other examples. One has The Mayibuye Archives at University of Western Cape ${ }^{6}$, which was linked to Robben Island. In fact, there was a partnership between Robben Island and UWC called the Mayibuye Archives, and it also collected material from the exile movements, materials that were collected by for example, International Defence and Aid Fund (IDAF), material from the ANC, PAC, Communist Party, and from individuals who had collected materials and conducted interviews, etc. It became part of a project of the development of Robben Island as a Museum with its own archives.

The final example is the ANC archives. It was repatriated from various exile experiences, became the official archives and then was deposited at the University of Fort Hare. It is not supposed to be an "ANC" archives but a liberation movements' archives. It is overwhelmingly ANC archives, but there is material of the PAC and other movements. In broad terms, these are the main categories of the archives we have in the country.

Finally, in a context of neoliberal austerity, what is happening is that the philanthropic organizations that supported a lot of work around archives in the early 2000s, have withdrawn funding. So, it has become more difficult for independent archives to continue operating and to grow in the way they did in the early 2000. At the same time, there is a crisis of the National Archives.

\section{Why would a university be interested in an archive?}

To answer the first part of the question, I want to draw a distinction between two kinds of South African universities. Some were broadly anti-apartheid, progressive, ranging from liberal to radical. These universities, mainly the English-speaking universities: University of Cape Town, Wits, Rhodes, Natal, as well as, the University of Western Cape and Fort Hare. Those universities which could be regarded as having been autonomous, anti-apartheid bastions, would have generally supported the idea of creating independent archives. So, those archives did not come under the control of the apartheid state. As stated earlier, organizations like the Anglican Church deposited their archives with Historical Papers. So did many other organizations because they regarded these places as having the expertise, autonomy, and proper professional practices that they did not have in their own organization. Of course,

\footnotetext{
${ }^{6}$ URL: https://mayibuyearchives.org/ (accessed 05.10.2021).
} 
another question arises: why did those organizations not develop their own archival practices? This is an issue one has to confront in the country. Historically it was obviously a good idea to secure archives at universities where there were some guarantees for proper attention to the material, proper custodial and preservation practices. But, in fact, it also meant that all the pressure was put on these institutions to play an archivist role that the broader society should play. I don't mean by that only churches, companies and other major institutions but there are challenges. Many organizations don't have the capacity and are unlikely in the near future to have the capacity to develop and preserve archives. In the context of Apartheid, it made sense for organizations that may have feared they could lose their material through the intervention of the state, through raids, and looking for ban material, to have that material safely secured at university.

The state was not able to intervene in the universities, formally speaking. Universities have autonomy in the country. What that means, it is better to refer to it as relative autonomy. Through pieces of legislations, the state can't intervene in universities. So, in fact, to make the point very sharply, the police are not allowed onto universities campus without the permission of university management. So, there is a line. What that means, de facto, is the archives are protected. The state could ban material but it could not stop the banned material to be stored in the universities' archives.

\section{What is the distinction between independent and activist archivists?}

There is a distinction because the independent archives don't necessarily regard themselves as activists' archives. Of course, activist archives are independent. Let's takes the example of Historical papers and SAHA. Even though there is an important overlap in the practices of the two, Historical Papers sees itself as a collector of radical archives, not activist even if it is independent and has archives of trade unions, social movements, underground organization, leading south African activists, etc. In terms of what they have, historically speaking, it has custodianship over archives that under apartheid would have been regarded as radical. And it continues to acquire archives of that nature. But it does not self-define as an activist archive.

What is an activist archive? Conventionally archives are involved in acquisition and preservation of materials, that is, a role of custodianship. These practices are absolutely crucial for archives and without them there would a serious crisis. However, it is generally a rather passive role in terms of how such archives relate to civil society and particularly contemporary struggles. SAHA also acquires historical material of movements, organisations and people, who may no longer be active.

Importantly, however, SAHA actively engages civil society and social movements, and works with them to develop their archives, as they are actively involved in various forms of protests, campaigns and struggles. That is not usually what archives because it means having a relationship with movements that are still involved in various struggles, contestations and protests, to help them think about the importance of archives. It is a continuously evolving process of creating and reimagining archives with such movements. 
To give an example, SAHA has a collection of materials on a movement called the AntiPrivatization Forum, ${ }^{7}$ which was a key anti-neoliberal movement, that existed from the early 2000s. That collection was created by activists in the movement to be a resource for contemporary movements and researchers on social movements. This is a critical issue for an activist archive: that the material could be used to assist movements currently involved in campaigns. Doing this is quite a challenge and sometimes we fail. For example, we tried to persuade activists in the Fees Must Fall movements to collect archives ${ }^{8}$. We made overtures to the students but they were not ready to archive their struggles. It was a little frustrating but entirely understandable. When one is involved in intense protests, archives are not readily perceived as important.

It means also being involved in campaigns around access to archives. SAHA has taken the state to court to compel the state to make state archives accessible to people who want to do research through the application of PAIA (Public Access to information Act). SAHA has been one of the key organizations that has used this piece of legislation. But it can take years to complete cases, sometimes four or five years, to get access to materials which should be in public domain. So, when I talk about activism it is both about a practice of archiving, a practice of access to information and working with civil society, social movements, to think archivally, to create the archives in the course of the struggle, to create this archive of movements.

Those are the intentions and we are also involved in training. You may know from the conference that we created a booklet for civil society 9 to know how to get access to archives. That is about access to information. There is a range of activities that constitute the idea of an activist archive. Activist archives are by definition independent, of the state and of capital. SAHA is probably the only archive that defines itself in that way in the country.

\section{Independent of state and of capital, how do you run these archives? How did this idea of the hub come out?}

The issue of funding is a big issue, a big problem that confronts independent archives because the custodial work, the work of preservation, all require expertise. They also require proper infrastructure that cannot be a short-term investment. It has to be long term. There are few organizations that are prepared to make long-term investments in independent archives. Activist archives which are broadly on the side of social movements and civil society. These movements may be engaged in protests against the very organizations from which one wants to get funds, such as the state, private companies and even philanthropic organizations. This makes the funding terrain difficult, especially for archives that want to maintain their independence. South Africa benefited during the early years of transition towards democracy when there was a lot of interest from philanthropic organizations to invest in aspects of South

\footnotetext{
7 In 2000, this movement brought together a group of activists from the townships of the Gauteng province in which Johannesburg and Pretoria are located. It denounced the urban plan proposed by the municipality of Johannesburg, entitled iGoli 2002, privatizing many services. He continued his activity for a decade.

8 In 2015, a large student movement to denounce university fees shook the South African campus. A series of other issues were subsequently evoked by students.

9 Conference: "Public History and Archiving from Below", Johannesburg, 6-9 June 2019. Booklet, online. URL: https://www.wits.ac.za/history-workshop/archives-guide/ (accessed 05.10.2021).
} 
Africa's development. One of those was the Atlantic Philanthropic Society ${ }^{10}$ which, for 20 years, invested a considerable amount of money in independent archives. The Truth and Reconciliation Commission (TRC) process produced significant interest in memory, history, heritage, and archives. Out of that process, South Africa became a site of the development, debates and contestation, redefinition of ideas of archives. The universities became one of the key sites where these discussions took place. It involved other people but it was concentrated here.

In those years, it was relatively easy to raise funds for archives, not a huge amount of money, but independent archives and civil society organizations operate on shoestring budget. They work as NGOs. This is the experience of SAHA. We only have one director and volunteers, interns, part-time workers, and the like. It is difficult to pinpoint a moment, maybe over the last ten years, when it became more difficult to generate income even from philanthropic organizations, which began to withdraw from South Africa. An important source of financial support ceases to exist.

What is the answer? I do not know. This comes to the archival hub in Wits.

What SAHA confronted was that there was the continuous need for SAHA, which is a growing archive. And yet, the prospect of raising enough money to maintain it and to run it professionally was declining. Therefore, we decided to approach Wits University to put to them that they have a responsibility as a public institution interested in research and learning education to contribute to the continuous existence of SAHA.

Fortunately, the previous vice chancellor, Adam Habib, understood the importance of the archives and readily agreed that we should find a way of bringing SAHA back into the university. Now, what does that mean? We say that SAHA is reintegrating in the university. SAHA had space at Wits university until about 8 years ago. In fact, SAHA had offices where Historical Papers is, and operated from there. But we decided from various reasons, at a certain point it was better for SAHA to move out of the university. We therefore proposed a process of reintegration. But there is a specific context that I described earlier, of the crisis of archives, the lack of funding, etc. at the time when there is in fact a dire need for independent archives. If one surveys the landscape there are probably two, three, maximum four independent archives based at universities that are functioning properly. If you consider we are a country of 60 million people, with hundreds if not thousands of organizations, you only have handful of archives working. It may appear, from outside, that to have SAHA, Historical Papers, Killie Campbell, Mayibuye Archives is fantastic. But we need ten times that number to deal properly with archives. The upward trajectory we had in terms of interest in archives after the TRC, is now in decline. We tried to stop this decline and to rebuild the archive. That was the context. The vice chancellor proposed the creation of a committee to think about what it means to reintegrate SAHA to university. What we did not want is an administrative decision. It was the opportunity to rethink the archives at the university.

We wrote a document and a proposal to establish, initially virtually, something called the "archival hub". This hub comprises three entities, Historical Papers and Research Archives,

\footnotetext{
10 URL: https://www.atlanticphilanthropies.org/our-story (accessed 05.10.2021).
} 
which is the existing strong archival entity at the university, SAHA which conceives itself as activist archives, with significant collections, and History Workshop. Those three entities will constitute the archival hub. Three or four key things bring them together. First, a commitment to the archives; second, thinking about the possible research and teaching consequence of creating an archival hub. That could mean creating a course around archives, getting more students working in the archives, reimagining the archives, and doing more archivally-based research. There is not really a course they can attend that deals with the archive. What we do, and we have the workshop in that purpose, is about the use of archives. So, we need to mobilize the knowledge that exists already to think deeply about the archives. Thirdly, is to develop the activist work and that includes the engagement of the archival hub with public outside university, civil society, individuals, organization, movements. That is where the combination of the idea of activist archive and public history come together.

We want to organize one or two workshops over a number of days (when Covid allows us to do), with organizations around archives, to train people in movements about how they must preserve their materials, and develop their own archives, etc. Of course, it will have to go into the digital domain. So, when I switch on my phone, I have fifty or sixty messages from different groups of protest. This information can become archives, but no one in these movements gives any attention to create archives. Why should they? They are busy organizing a protest, a march etc. to think about archive is number twenty on the 'to do' list. And yet, again you know better than many, for me the reference was the Arab uprising and you know how that movement produced archives in very difficult situations, myriad of complications, but complications that can be identified. What happens to people who post on Facebook for example, or WhatsApp, or created video, what is that? I can see videos all the time of people protesting, marching. What do you do or who is doing it? No one.

So, we need to think through these things, it requires engagement on public history, activist archives, that kind of nexus of issues. Finally, to come back to the overarching context - there is a crisis, independent and activist archives need to play a more active role in promoting archives in the country. That means things such as convening meetings, with other archivists, examining the shortcomings and the crisis of the National Archives, make an argument for the need to train more archivists. To take an example of the extent of the crisis: we are busy thinking about appointing an archivist at SAHA, but cannot think of anyone in the country who could apply for the post. That is because there has not been training of archivists. When the current generation of archivists retire there might not be anyone to replace them. Even if we have independent archives, if you don't have people who have the expertise, the training, the qualifications and the imagination to think about archives beyond preservation, we are in trouble. So, these are the four overarching criteria or objectives that we set ourselves for the archive hub. It will take some time to implement. It is a slow but ongoing process.

Matthieu Rey IFPO Beyrouth/ Research associate at History Workshop (University of Witwatersrand) 